УдК $615.015 .11: 615.261 .1: 615.032$

I. А. Кравченко ${ }^{1,2}$, д.б.н., професор,

Б. В. Приступа ${ }^{1}$, аспірант,

М. В. Кірєва ${ }^{1}$, аспірант,

А. О. Кобернік ${ }^{1}$, к.б.н., старший викладач

${ }^{1}$ Одеський національний університет імені I. I. Мечникова,

кафедра фармацевтичної хімії

вул. Дворянська, 2, Одеса, 65082, Україна, e-mail: koberni@mail.ru

${ }^{2}$ Фізико-хімічний інститут імені О. В. Богатського НАН України,

Люстдорфська дорога, 86, Одеса, 65080

\title{
ПРОТИЗАПАЛЬНА АКТИВНІСТЬ ЕСТЕРІВ ІБУПРОФЕНУ ПРИ ТРАНСДЕРМАЛЬНОМУ ВВЕДЕННІ
}

\begin{abstract}
На моделі карагенін-індукованого запалення встановлено, що рівень протизапальної активності естерів ібупрофену з різною довжиною вуглецевого ланцюга при їх трансдермальному введенні за показниками динаміки зміни ширини та об’єму осередку запалення не поступаються ефекту референтпрепарату - 5 \% мазі ібупрофену, а у випадку використання довголанцюгових естерів навіть перевищують його ефект.
\end{abstract}

Ключові слова: протизапальна активність, естери, ібупрофен, карагенін, трансдермальне введеня.

Однією з проблем сучасної фармакології є підвищення ефективності лікування захворювань, що супроводжуються розвитком запалення. Для вирішення цієї проблеми створюють лікарські форми з протизапальними та репаративними властивостями, які не викликали б токсичної та побічної дії. Одним із шляхів досягнення цієї мети є цілеспрямований синтез нових лікарських препаратів [8].

В роботі увагу зосереджено на протизапальних засобах нестероїдної структури, які набули найбільш широкого використання у практичній діяльності лікарів [5].

Ібупрофен - відомий нестероїдний протизапальний препарат (НПЗП) 3 протизапальною, аналгетичною та помірною жарознижуючою активністю. У основі механізму його дії - інгібірування біосинтезу простагландинів $\mathrm{E}$ i F як на центральному, так і на периферичному рівнях. Для лікування місцевих запальних процесів широко використовуються мазі, що містять ібупрофен. Дорослим і дітям старше 14 років призначають нанесення тонкого шару крему 3-4 рази на добу. Оптимізувати процес лікування можливо за рахунок створення лікарських форм з пролонгованою терапевтичною дією [3]. Таким чином, актуальним є створення похідних на основі ібупрофену, яким було б притаманно збільшення часу утримання активної молекули в організмі як за рахунок 
збільшення ліпофільності, так і за рахунок повільного гідролізу, який приводить до пролонгованої дії.

Крізьшкірне введення є особливою формою зовнішнього застосування та відрізняється тим, що активна речовина потрапляє в кровообіг, минаючи шлунково-кишковий тракт та перше проходження крізь печінку, і завдяки цьому зменшуються побічні ефекти, притаманні пероральному введенню.

Мета роботи - вивчення протизапальної активності м'яких лікарських форм з естерами ібупрофену при трансдермальному їх застосуванні у щурів на моделі карагенін-індукованого запалення.

\section{Матеріали та методи дослідження}

Для вивчення протизапальної активності було обрано естери ібупрофену, синтезовані на кафедрі фармацевтичної хімії ОНУ імені I. І. Мечникова. Досліди проводили на білих щурах-самцях, масою 180-200 г, отриманих 3 віварію Одеського національного медичного університету. Під час досліду тварини утримувалися в умовах віварію на стандартному раціоні з вільним доступом до води та їжі. Експериментальні дослідження проводились відповідно до методичних рекомендацій Державного фармакологічного центру МОЗ України [4] та комісії з біоетики ОНУ імені I. I. Мечникова МОН України (протокол № 2 від 14 квітня 2009 р).

Отримання естерів ібупрофену, що містять як спиртову частину залишки метилового та етилового спиртів проводили безпосередньо у середовищі спирту. Для одержання естерів із залишками радикалів гептилового та октилового спиртів, реакцію здійснювали в бензолі, у колбі з насадкою Діна-Старка [7].

Чистоту одержаних естерів перевіряли методом тонкошарової хроматографiї (ТШХ) у системі - гептан-хлороформ-етилацетат 1:1:0,5. Чистоту та індивідуальність отриманих сполук оцінювали методом ТШХ, а також за ЯМР-, мас- та ІЧ-спектрами.

Гостру запальну реакцію (набряк) викликали субплантарним уведенням 0,2 мл 0,2 \% розчину карагеніну в задню кінцівку дослідних щурів [6]. Після розвитку запалення проводили лікування щурів шляхом трансдермального введення ібупрофену та синтезованих естерів на місце ураження. Було підібрано оптимальне співвідношення допоміжних компонентів для виготовлення мазей на основі естерів ібупрофену. До складу мазей входили ПЕГ-1500, ПЕО-400 та 1,2-пропіленгліколь у співвідношенні $4: 2: 3$, відповідно.

Для лікування використовували 4 різновиди 5 \% мазі естерів ібупрофену в молярному перерахунку на активну речовину (ібупрофен).

Для порівняння використовували дві групи тварин, одну з яких лікували шляхом нанесення на шкіру 5 \% мазі ібупрофену (Долгіт крем, виробник: ДОЛОРГИТ ГмбХ і Ко. КГ, Німеччина) та другу - контрольну групу без лікування. 
Структура досліджуваних сполук наведена в табл. 1.<smiles>[R]OC(=O)C(C)c1ccc(CC(C)C)cc1</smiles>

Досліджувані сполуки

\begin{tabular}{|c|l|c|c|c|}
\hline № & \multicolumn{1}{|c|}{ Назва } & $-\mathbf{R}$ & $\begin{array}{c}\text { Молярна маса } \\
\text { (М, г/моль) }\end{array}$ & $\begin{array}{c}\text { Вміст естеру, } \\
\text { г /100 г мазі }\end{array}$ \\
\hline I & ібупрофен & $-\mathrm{H}$ & 206 & 4,996 \\
\hline II & $\begin{array}{l}\text { метиловий естер } \\
\text { ібупрофену }\end{array}$ & $-\mathrm{CH}_{3}$ & 220 & 5,336 \\
\hline III & $\begin{array}{l}\text { етиловий естер } \\
\text { ібупрофену }\end{array}$ & $-\mathrm{C}_{2} \mathrm{H}_{5}$ & 234 & 7,376 \\
\hline IV & $\begin{array}{l}\text { гептиловий естер } \\
\text { ібупрофену }\end{array}$ & $-\mathrm{C}_{7} \mathrm{H}_{15}$ & 304 & 7,716 \\
\hline V & $\begin{array}{l}\text { октиловий естер } \\
\text { ібупрофену }\end{array}$ & $-\mathrm{C}_{8} \mathrm{H}_{17}$ & 318 & 73676 \\
\hline
\end{tabular}

Оцінку результатів експериментального дослідження проводили на підставі динаміки зміни об'єму ураженої кінцівки (об’єм визначали методом волюметрії), а також рівня лейкоцитів у крові $[1,2]$.

Для підрахунку кількості лейкоцитів відбирали кров 3 хвостової вени дослідних тварин. Визначення кількості лейкоцитів проводили в 100 великих квадратах камери Горяєва після лізису еритроцитів 3-5 \% розчином оцтової кислоти, підфарбованим декількома краплями розчину метиленового синього. Результати перераховували на 1 мкл крові, враховуючи розведення крові $(1: 20)$.

Статистичні показники обчислювали за допомогою програмного пакету Microsoft Excel.

\section{Результати та їх обговорення}

Показано, що об'єм уражених кінцівок усіх щурів дослідних груп після введення флогогенного агенту (через 24 год) збільшується в середньому в 2 рази, однак трансдермальне введення ібупрофену та його естерів сприяє тому, що вже на 2 добу досліду простежується чітка тенденція до зниження об'єму осередку запалення (табл. 2). 
Таблиця 2

Протизапальна активність коротко ланцюгових

та довголанцюгових естерів ібупрофену за об'смом уражених кінцівок щурів,

\% до показників інтактних тварин $(n=10)$

\begin{tabular}{|c|c|c|c|c|c|c|}
\hline \multirow{3}{*}{$\begin{array}{c}\text { Тривалість } \\
\text { лікування, } \\
\text { доба }\end{array}$} & \multicolumn{6}{|c|}{ Група тварин } \\
\hline & \multirow{2}{*}{$\begin{array}{c}\text { Контрольна } \\
\text { група (за- } \\
\text { палення) }\end{array}$} & \multirow[b]{2}{*}{ Ібупрофен } & \multicolumn{2}{|c|}{ Коротколанцюгові } & \multicolumn{2}{|c|}{ Довголанцюгові } \\
\hline & & & $\begin{array}{c}\text { Метило- } \\
\text { вий естер } \\
\text { ібупрофену }\end{array}$ & $\begin{array}{c}\text { Етиловий } \\
\text { естер ібупро- } \\
\text { фену }\end{array}$ & $\begin{array}{c}\text { Гептило- } \\
\text { вий естер } \\
\text { ібупрофену }\end{array}$ & $\begin{array}{c}\text { Октиловий } \\
\text { естер ібупро- } \\
\text { фену }\end{array}$ \\
\hline $\begin{array}{c}\text { Інтактні } \\
\text { показники }\end{array}$ & $100,0 \pm 1,1$ & $100,0 \pm 1,2$ & $100,0 \pm 1,5$ & $100,0 \pm 1,3$ & $100,0 \pm 0,4$ & $100,0 \pm 0,2$ \\
\hline 1 & $205,0 \pm 2,5$ & $191 \pm 4,3^{*}$ & $196,0 \pm 2,3 *$ & $186,6 \pm 2,3^{*}$ & $201,0 \pm 2,3$ & $193,0 \pm 2,3 *$ \\
\hline 2 & $198,0 \pm 3,1$ & $147,4 \pm 4,1^{*}$ & $129,4 \pm 2,6^{*}$ & $142,3 \pm 2,6^{*}$ & $124,0 \pm 2,6^{*}$ & $133,6 \pm 2,6^{*}$ \\
\hline 3 & $190,0 \pm 2,4$ & $139,5 \pm 3,5^{*}$ & $122,2 \pm 1,6^{*}$ & $136,7 \pm 1,6^{*}$ & $111,6 \pm 1,6^{*}$ & $125,4 \pm 1,6^{*}$ \\
\hline 4 & $183,0 \pm 5,5$ & $133,8 \pm 5,7^{*}$ & $119,3 \pm 5,1^{*}$ & $123,1 \pm 5,1^{*}$ & $107,5 \pm 5,1^{*}$ & $116,4 \pm 5,1^{*}$ \\
\hline 5 & $171,0 \pm 3,9$ & $124,8 \pm 3,3^{*}$ & $115,4 \pm 3,2 *$ & $119,7 \pm 3,2^{*}$ & $110,0 \pm 3,2 *$ & $110,0 \pm 3,2 *$ \\
\hline 6 & $161,0 \pm 4,2$ & $114,6 \pm 2,6^{*}$ & $107,8 \pm 3,5^{*}$ & $112,3 \pm 3,5^{*}$ & $107,4 \pm 3,5^{*}$ & $108,2 \pm 3,5^{*}$ \\
\hline 7 & $142,0 \pm 2,5$ & $111,2 \pm 1,6^{*}$ & $110,3 \pm 1,2 *$ & $114,6 \pm 1,2^{*}$ & $98,7 \pm 1,2 *$ & $104,3 \pm 1,2 *$ \\
\hline 8 & $134,0 \pm 3,4$ & $104,4 \pm 0,4^{*}$ & $97,5 \pm 1,1^{*}$ & $104,9 \pm 1,1^{*}$ & $94,7 \pm 1,1^{*}$ & $99,1 \pm 1,1^{*}$ \\
\hline 9 & $134,0 \pm 2,4$ & $102,7 \pm 1,0^{*}$ & $98,2 \pm 1,6^{*}$ & $106,6 \pm 1,6^{*}$ & $92,1 \pm 1,6^{*}$ & $96,7 \pm 1,6^{*}$ \\
\hline 10 & $134,0 \pm 1,2$ & $104,4 \pm 0,8^{*}$ & $102,4 \pm 5,1^{*}$ & $105,5 \pm 5,1^{*}$ & $92,1 \pm 5,1^{*}$ & $96,7 \pm 5,1^{*}$ \\
\hline
\end{tabular}

Примітка. * - $\mathrm{P}<0,05$ порівняно $з$ контрольною групою.

Відмічено, що вже на 2 добу досліду об'єм набряку значно зменшується при використанні ібупрофену на 26 \% та його естерів - на 35 (метиловий) та $29 \%$ (етиловий), порівняно з показниками контрольної групи.

За умов лікування коротколанцюговими естерами, об'єм ураженої кінцівки досяг вихідних показників на 6 добу дослідження, а довголанцюговими естерами - на 7 добу, тоді як для групи, яку лікували ібупрофеном, він залишався збільшеним. На 8-му добу дослідження відмічено, що показники об'єму кінцівок групи, яку лікували ібупрофеном достовірно не відрізнялись від інтактних.

У контрольної групи тварин, яку не лікували, на 10-й день дослідження об’єм уражених кінцівок перевищував початкові показники на 34 \%. 
Необхідно відмітити, що група, яку лікували гептиловим естером, показала кращий результат, порівняно з іншими групами. Показники цієї групи були нижчими за групу, яку лікували референт-препаратом - мазь ібупрофену.

Таким чином, встановлено, що за протизапальною активністю коротколанцюгові естери не поступаються ібупрофену, а довголанцюгові естери - перевищують його показники.

Процес запалення в організмі завжди супроводжується порушенням гомеостазу формених елементів крові, особливо лейкоцитів. Враховуючи це, результати дослідження такого маркера запалення як вміст лейкоцитів у крові дослідних тварин наведено у табл. 3 .

Таблиця 3

Вміст лейкоцитів у крові щурів за карагенін-індукованого запалення та лікування мазями, що містять естери ібупрофену, (“10\%/л)

\begin{tabular}{|l|c|c|c|c|c|c|c|}
\hline \multirow{2}{*}{$\begin{array}{c}\text { Група тварин } \\
\text { (n=5) }\end{array}$} & \multicolumn{7}{|c|}{ Тривалість лікування, доба } \\
\cline { 2 - 8 } & $\mathbf{0}$ & $\mathbf{1}$ & $\mathbf{2}$ & $\mathbf{4}$ & $\mathbf{6}$ & $\mathbf{8}$ & $\mathbf{1 0}$ \\
\hline Контрольна група & $10,6 \pm$ & $13,2 \pm$ & $15,2 \pm$ & $23,3 \pm$ & $21,0 \pm$ & $18,9 \pm$ & $14,8 \pm$ \\
(запалення) & 0,2 & 0,2 & 0,4 & 0,1 & 0,3 & 0,2 & 0,1 \\
\hline Метиловий естер & $10,7 \pm$ & $20,9 \pm$ & $17,8 \pm$ & $14,5 \pm$ & $13,0 \pm$ & $10,9 \pm$ & $9,5 \pm$ \\
ібупрофену & 0,2 & $0,3^{*}$ & $0,1^{*}$ & $0,6^{*}$ & $0,2^{*}$ & $0,6^{*}$ & $0,4^{*}$ \\
\hline Етиловий естер & $10,5 \pm$ & $16,4 \pm$ & $15,3 \pm$ & $14,9 \pm$ & $13,8 \pm$ & $12,3 \pm$ & $11,8 \pm$ \\
ібупрофену & 0,3 & $0,4^{*}$ & $0,3^{*}$ & $0,2^{*}$ & $0,4^{*}$ & $0,6^{*}$ & $0,2^{*}$ \\
\hline Гептиловий естер & $9,9 \pm$ & $16,5 \pm$ & $15,6 \pm$ & $11,3 \pm$ & $11,9 \pm$ & $12,2 \pm$ & $10,7 \pm$ \\
ібупрофену & $0,1^{*}$ & $0,3^{*}$ & $0,2^{*}$ & $0,4^{*}$ & $0,2^{*}$ & $0,3^{*}$ & $0,1^{*}$ \\
\hline Октиловий естер & $10,2 \pm$ & $24,8 \pm$ & $18,9 \pm$ & $17,7 \pm$ & $15,8 \pm$ & $12,0 \pm$ & $11,2 \pm$ \\
ібупрофену & 0,2 & $0,6^{*}$ & $0,5^{*}$ & $0,4^{*}$ & $0,2^{*}$ & $0,6^{*}$ & $0,5^{*}$ \\
\hline \multirow{2}{*}{ Ібупрофен } & $8,9 \pm$ & $9,6 \pm$ & $13,9 \pm$ & $16,2 \pm$ & $12,7 \pm$ & $11,5 \pm$ & $12,4 \pm$ \\
& $0,1 *$ & $0,3^{*}$ & $0,4^{*}$ & $0,5^{*}$ & $0,3^{*}$ & $0,1^{*}$ & $0,4^{*}$ \\
\hline
\end{tabular}

Примітка. * - ${ }^{2}<0,05$ порівняно 3 контрольною групою.

Через 24 год після введення карагеніну було відмічено збільшення рівня лейкоцитів у крові тварин усіх дослідних груп. В наступні 2 доби експерименту кількість лейкоцитів перевищувала діапазон нормальних величин у всіх групах, крім групи, яку лікували ібупрофеном. На 4-6-ту добу досліду рівень лейкоцитів досяг фізіологічної норми в щурів, яких лікували ібупрофеном та його естерами.

\section{Висновок}

На моделі карагенін-індукованого запалення рівень протизапальної активності довголанцюгових естерів ібупрофену при трансдермальному введенні 
за показниками динаміки зміни об'єму осередку ураження перевищує ефект референт-препарату - мазі ібупрофену та досягають рівня інтактних показників уже на 8-му добу.

\title{
Список використаної літератури
}

1. Головенко Н. Я. Биохимическая фармакология пролекарств / Н. Я. Головенко, И. А. Кравченко. - Одесса: Екологія, 2007. - 358 с.

2. Камышников В. С. Справочник по клинико-биохимическим исследованиям и лабораторной диагностике (2-ое издание, переработанное и дополненное) / В. С. Камышников. - Москва: МЕДпресс-информ, 2004. $-920 \mathrm{c}$

3. Коваленко В. Н. Компендиум. Лекарственные препараты / Под редакцией В. Н. Коваленко, А. П. Викторова. - Киев: Морион, 2005. - 100 с.

4. Стефанов О. В. Доклінічні дослідження лікарських засобів. Методичні рекомендації / О. В. Стефанов. Київ: МОЗ України. Державний фармакологічний центр, 2001. - 527 с.

5. Чеснокова Н. П. Воспаление: этиология, патогенез, патогенетическое обоснование принципов терапии / Н. П. Чеснокова, Т. А. Невважай, О. Л. Морозова. - Саратов: СГМУ, 2008. - С. 3-45.

6. Morris C. J. Carrageenan-induced paw edema in the rat and mouse / C. J. Morris // Methods Mol. Biol. 2003. - V. 225. - P. 121.

7. Jan M. Schwab. Resolvin E1 and protectin D1 activate inflammation-resolution programme / Jan M. Schwab, Nan Chiang, Makoto Arita, Charles N. Serhan // Nature. - 2007. - V. 447. - P. 869-874.

8. Zeuzem S. Peginterferon alfa-2a in patients with chronic hepatitis C / S. Zeuzem, S. V. Feinman, J. Raseneck // N. Engl. J. Med. - 2000. - V. 343, N 23. - P. 1666-1672.

Стаття надійшла до редакції 12.12.2014

\author{
И. А. Кравченко ${ }^{1,2}$, Б. В. Приступа ${ }^{1}$, М. В. Кирева ${ }^{1}$, А. А. Коберник ${ }^{1}$ \\ ${ }^{1}$ Одесский национальный университет имени И. И. Мечникова, \\ кафедра фармацевтической химии \\ ул. Дворянская, 2, Одесса, 65082, Украина, e-mail: koberni@mail.ru \\ ${ }^{2}$ Физико-химический институт имени А. В. Богатского НАН Украины, \\ Люстдорфская дорога, 86, Одесса, 65080
}

\section{ПРОТИВОВОСПАЛИТЕЛЬНАЯ АКТИВНОСТЬ СЛОЖНЫХ ЭФИРОВ ИБУПРОФЕНА ПРИ ТРАНСДЕРМАЛЬНОМ ВВЕДЕНИИ}

Резюме

В результате проведенного исследования было показано, что уровень противовоспалительной активности эфиров ибупрофена с разной длиной углеродной цепи при их трансдермальном введении по показателям динамики изменения объема очага воспаления не уступают эффекту референт-препарата - мази ибупрофена на модели карагенин-индуцированого воспаления. А в случае использования длинноцепочечных эфиров действуют лучше препарата сравнения.

Ключевые слова: противовоспалительная активность, эфиры, ибупрофен, каррагенин, трансдермальное введение. 
I. A. Kravchenko ${ }^{1,2}$, B. V. Prystupa ${ }^{1}$, M. V. Kireva ${ }^{1}$, A. O. Kobernik ${ }^{1}$

${ }^{1}$ Odesa National Mechnykov University, Pharmaceutical Chemistry Department

2, Dvoryanska str., Odesa, 65082, Ukraine, e-mail: koberni@mail.ru

${ }^{2} \mathrm{~A}$. V. Bogatsky Physico-Chemical Institute of NAS Ukraine

86, Lustdorfska doroga, Odesa, 65080, Ukraine

\section{ANTI-INFLAMMATORY ACTIVITY OF IBUPROFEN ESTERS}

\section{BY TRANSDERMAL DELIVERY}

\section{Summary}

As a result of the study, it was shown that the level of anti-inflammatory activity ointment with ibuprofen esters with different length of radical in transdermal delivery was not different from anti-inflammatory activity of the commercial referent drug - ibuprofen ointment and in some cases, were more active on the model of carrageenan-induced inflammation.

Key words: anti-inflammatory activity, ibuprofen, esters, carrageenan, transdermal delivery. 